\title{
An Empirical Study on Attrition \& Employee Retention Initiatives With Reference To Flow Link Systems Private Limited, Coimbatore
}

\author{
${ }^{1}$ Dr.A.Kumudha, ${ }^{2}$ R.Saranya \\ ${ }^{1}$ Associate professor, ${ }^{2}$ M.Phil Research Scholar \\ Deptt of Business Management, PSGR Krishnammal College for Women, Coimbatore
}

\begin{abstract}
Employee retention and turnover are topics of a lot of conversations centering on HR. The challenge for the HR professionals today is not only to attract and attain the right employees, but also to innovatively train them. The research was conducted in Flow link systems Pvt Ltd which comes under metal casting industries. The company is located in Arasur which is started as the foundry division and is continued to expand to the present level. Total employees are 655 and, the researcher has selected 150 samples through stratified disproportionate random sampling method. The researcher has found that the employees are highly satisfied with the work load and lead time and working environment, relationship between supervisors and colleagues are neutral. Employees are dissatisfied with their training and development, salary structure and the suggestions are made by the researcher for the same to retain the employees towards their work.
\end{abstract}

Keywords: Employee Attrition, Retention

\section{INTRODUCTION}

A large sum of money is being spent on technology up gradation, but the real backbone of the organization is its people. The importance of retaining good employees is reflected from the rule of thumb that "Technology makes up to 10 percent of a business processes, employees and culture makes up 90 percent." As the worker decides to take the leap or not, his predicament is made worse by his present firm whose members decide to try every trick in the book to persuade him to say. If he decides to leave, the story does not finish here. Rather, the pressurizing tactics only get worse.

\section{EMPLOYEE RETENTION}

Employee retention is the effort by employers to encourage current employees to remain employed with the organization.It is better to retain the existing talent than to hire continuously. Retaining good employees has always been an issue of utmost importance. Employees today are different. They are not the ones who don't have good opportunities in hand. A good employer should know how to attract and retain its employees.

\section{ATTRITION}

Employee attrition is a chronic disturbance that the HR department is exposed to. The recent times have witnessed a steep increment in the employee turnover. It's important to know whether their employees are dissatisfied or there any other reasons for leaving the job. Before taking sudden action it is always wise to investigate into the root cause of the issue.

\section{REVIEW OF LITERATURE}

Satish Deshopande.P \& Damodar Golhar. Yhad stated that in the recent years, small firms have accounted for nearly $90 \%$ of the net new jobadded in the U.S. since small firms employment nearly half of the American workforce, their success is critical for the economy. To be successful in a global market, a small firm needs a highly motivated, skilled and satisfied workforce that can produce quality goods at low costs. However, to develop such a workforce, a firm has to implement an appropriate human resource 
management (HRM) strategy. Unlike large business, published research further indicates that recruiting, motivating, and retaining employees is one of the biggest problems for small firms.

Govindaraj.S had concluded that it is Hr's job; though not HR's job alone, to champion and shepherd effective human resource management practices at both the strategic and day-to- day levels. That is, to be effective human resource management practices must be grounded in two ways. First they must reflect companywide commitments as to how it will manage and relate to its employees. Secondly, HR must implement these commitments so that the ideals of the enterprise and deeds of its agents are congruent. Employee retention is also responsibility of HR.

Based on the researchers study in texcel international private limited, the employee retention measures are satisfactory and the suggestion given by the researcher can also be followed in the future for the betterment of employee retention. Thus the employee retention measures should be followed in the establishment in order to reduce the employee turnover.

\section{OBJECTIVES OF THE STUDY}

$>$ To study the employee attrition and retention factors.

$>$ To study the employer, employee relationship.

$>$ To study the measures taken by the company to retain their employees in the organization.

$>$ To study the proactive measure to reduce attrition

\section{RESEARCH METHODOLOGY}

\section{SAMPLING DESIGN}

The process of drawing a sample from a larger population is called sampling. Sampling is a part of population, which is studied in order to make inferences about the whole population. Totally there were 655 respondents, the researcher have selected 150 respondents through stratified disproportionate random sampling method.

TOOLS USED

$>$ Percentage analysis

$>$ Ranking method
Item wise-analysis

\section{LIMITATIONS OF THE STUDY}

This study is limited to the particular concern and the results are not generalized to other industries.

\section{RESULTS AND DISCUSSIONS}

TABLE.NO.1 RESPONDENT'S OPINION ABOUT WORK LOAD AND LEAD TIME

\begin{tabular}{|c|c|c|c|}
\hline $\begin{array}{c}\text { Opinion } \\
\text { Factors }\end{array}$ & $\begin{array}{c}\text { No Of } \\
\text { Respondents }\end{array}$ & $\begin{array}{c}\text { \%age Of } \\
\text { Respondents }\end{array}$ & $\begin{array}{c}\text { Total } \\
\text { Score }\end{array}$ \\
\cline { 1 - 3 } $\begin{array}{c}\text { Highly } \\
\text { satisfied }\end{array}$ & 97 & 64.67 & \\
\hline Satisfied & 33 & 22.00 & \\
\cline { 1 - 3 } Neutral & 15 & 10.00 & \multirow{2}{*}{672} \\
\cline { 1 - 3 } Dissatisfied & 5 & 3.33 & \\
\cline { 1 - 2 } $\begin{array}{c}\text { Highly } \\
\text { dissatisfied }\end{array}$ & - & \multicolumn{1}{|c}{} \\
\cline { 1 - 3 } TOTAL & 150 & 100 & \\
\hline
\end{tabular}

It is clear from the table no. 1 that 64.67 percent of the respondents are highly satisfied with the work load and lead time. It is similar to that study conducted in New Zealand by Pohlen Kean (2002) undertook a survey of the employees of 25 organizations. They found a clear relationship between the work-life balance policies on offer, employee's intentions to leave and actual turnover rates. Their study suggests that the work-life balance policies have a small overall net positive effect on staff turnover rates.

\section{TABLE.NO.2 RESPONDENT'S OPINION ABOUT TRAINING AND DEVELOPMENT ACTIVITIES}

\begin{tabular}{|c|c|c|c|}
\hline $\begin{array}{l}\text { Opinion } \\
\text { Factors }\end{array}$ & $\begin{array}{c}\text { No Of } \\
\text { Respondents }\end{array}$ & $\begin{array}{c}\text { \%age Of } \\
\text { Respondents }\end{array}$ & $\begin{array}{l}\text { Total } \\
\text { Score }\end{array}$ \\
\hline $\begin{array}{l}\text { Highly } \\
\text { satisfied }\end{array}$ & 23 & 15.33 & \multirow[t]{6}{*}{594} \\
\hline Satisfied & 33 & 22.00 & \\
\hline Neutral & 15 & 10.00 & \\
\hline Dissatisfied & 5 & 3.33 & \\
\hline $\begin{array}{c}\text { Highly } \\
\text { dissatisfied }\end{array}$ & - & - & \\
\hline TOTAL & 150 & 100 & \\
\hline
\end{tabular}

From the table no. 2 it reveals that 66.67 percent of the respondents are satisfied with the training and development activities. Training and Development 
aids in organizational development i.e. Organization gets more effective decision making and problem solving. It helps in understanding and carrying out organizational policies. It is also proved from the Hay Group study(2005) of more than 500,000 employees in 300 companies found that of 50 retention factors, such prisingly, pay was the least important at the top of the list, the most common reasons respondents gave for wanting stay within the company were career growth and training and development, exciting work and challenge.

\section{TABLE.NO.2 RESPONDENT'S OPINION ABOUT TRAINING AND DEVELOPMENT ACTIVITIES}

\begin{tabular}{|c|c|c|c|}
\hline $\begin{array}{c}\text { Opinion } \\
\text { Factors }\end{array}$ & $\begin{array}{c}\text { No Of } \\
\text { Respondents }\end{array}$ & $\begin{array}{c}\text { \%age Of } \\
\text { Respondents }\end{array}$ & $\begin{array}{c}\text { Total } \\
\text { Score }\end{array}$ \\
\hline $\begin{array}{c}\text { Highly } \\
\text { satisfied }\end{array}$ & 14 & 9.33 & \multirow{2}{*}{444} \\
\hline Satisfied & 28 & 18.67 & \\
\cline { 1 - 3 } Neutral & 58 & 38.67 & \\
\cline { 1 - 3 } Dissatisfied & 38 & 25.33 & \\
\cline { 1 - 3 } $\begin{array}{c}\text { Highly } \\
\text { dissatisfied }\end{array}$ & 12 & 8 & \\
\cline { 1 - 3 } TOTAL & 150 & 100 & \\
\hline
\end{tabular}

TABLE.NO.3 RESPONDENT'S OPINION ABOUT RELATIONSHIP WITH COLLEAGUES \& SUPERVISORS

\begin{tabular}{|c|c|c|}
\hline Factor & Total Score & Rank \\
\hline $\begin{array}{c}\text { Hike in } \\
\text { Salary }\end{array}$ & 650 & I \\
\hline $\begin{array}{c}\text { Sports } \\
\text { arrangement }\end{array}$ & 306 & V \\
\hline $\begin{array}{c}\text { Tour } \\
\text { arrangement }\end{array}$ & 327 & IV \\
\hline Get-together & 328 & III \\
\hline Promotion & 635 & II \\
\hline
\end{tabular}

It is evident from the table no. 3 that 38.67 percent of the respondents are neutral with the relationships with their colleagues and supervisors. It is relevant to the study conducted by William Bridges in the book, Managing Transitions, when people have a mutual trust and relationship, they are likely to progress. Bridges says that although the technique is easy to explain, it may not be as easy to put into action. Each individual can start by being trustworthy; this will create a trusting, loyal workforce.

TABLE .NO.4 DIFFERENT FACTORS AND ITS RANKS ACCORDING TO THE SATISFACTION LEVEL OF THE EMPLOYEES

\begin{tabular}{|c|c|c|}
\hline Factor & Total Score & Rank \\
\hline Salary / Perquisites & 424 & III \\
\hline Working Environment & 574 & I \\
\hline $\begin{array}{c}\text { Employer, employee } \\
\text { relationship }\end{array}$ & 395 & IV \\
\hline Work schedule & 365 & V \\
\hline Job security & 488 & II \\
\hline
\end{tabular}

It is identified from the table no.4 that the Working environment gets high score and it gets I ${ }^{\text {st }}$ Rank from the respondents, Job security follows the first factor and it gets II nd Rank from the respondents, Salary / Perquisites gets III ${ }^{\text {rd }}$ Rank, Employer, employee relationship will secured with IV ${ }^{\text {th }}$ Rank and work schedule comes last and it will gets $\mathrm{V}^{\text {th }}$ Rank.

TABLE .NO.5 MEASURES TO REDUCE EMPLOYEE'S ATTRITION IN THE ORGANIZATION AND ITS RANK

\begin{tabular}{|c|c|c|}
\hline Factor & Total Score & Rank \\
\hline Hike in Salary & 650 & I \\
\hline Sports arrangement & 306 & V \\
\hline Tour arrangement & 327 & IV \\
\hline Get-together & 328 & III \\
\hline Promotion & 635 & II \\
\hline
\end{tabular}

It is understood from the table no.5 that the Hike in Salary gets high score and it gets I ${ }^{\text {st }}$ Rank from the respondents, Promotion follows the first factor and it gets II ${ }^{\text {nd }}$ Rank from the respondents, Gettogether gets III ${ }^{\text {rd }}$ Rank, Tour arrangement secured with IV ${ }^{\text {th }}$ Rank and Sports arrangement comes last and it gets $\mathrm{V}^{\text {th }}$ Rank.

\section{SUGGESTIONS}

* It is found from the research that the employees are neutral with the relationships between their colleagues and supervisors. So they can assign team base 
work to their employee who can bring cooperation and mutual understanding among the employees. Retreats can also be an excellent way of improving employee relation.

* From the study it is found that employees are highly satisfied with the working environment and hence the management can follow the same processes which make the employees to stay in the organization.

The overall respondent was dissatisfied with the salary. Therefore the management can revise the salary by considering the cost of living index which is framed by the government which may satisfy the economic conditions of the employee.

\section{CONCLUSION}

In today's competitive world it is a great challenge to the organization to retain the employees. Retaining the key talent is essential for the organization for sustainable growth and hence countering and controlling the attrition factor. Thus employees are the real assets of any organization. Organization's sustained success depends on the extent to which it can retain its talent pools so as to have dedicated and committed cohesive work force attuned to rapid changes for focused growth. From the research it has been focused that the working environment is highly satisfied for the employees who can be maintained to improve the morale of the employees. It has also revealed from the research that the organization has to concentrate on workload and lead time, relationship between colleagues and supervisors, internal recruitments to retain the employees and reduce attrition. This research gave insight knowledge about the HR practices of the organization and retention strategies of the concern.

\section{REFERENCES:}

[1] Florida.R \& Goodnight.J (2005) 'Managing for creativity', Harvard Business Review, Vol.83, pp.124-131.

[2] Govindaraj.S (2010) had done a project on the topic "A Study on measures taken to retain employees with special reference to Texcel International Private Limited, Coimbatore"

[3] Jane Flaherty (2005) Trainer as retention agent,pp.61-62

[4] Satish Deshopande.P \& Damodar Golhar.Y (1994) Journal of small business management, vol.32

[5] William Bridges in the book, "Managing Transitions".

[6] www.flowlinksystems.com

[7] www.hrmba.blogspot.com

[8] www.businessdictionary.com/definition/ attrition.html.

[9] http://www.robinthompson.com/employ eeretention.htm

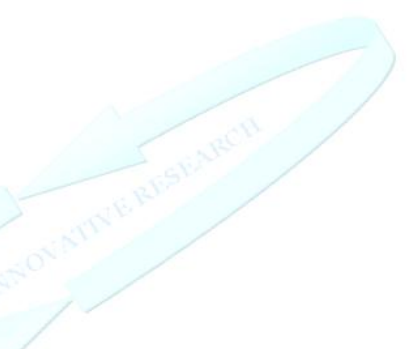

